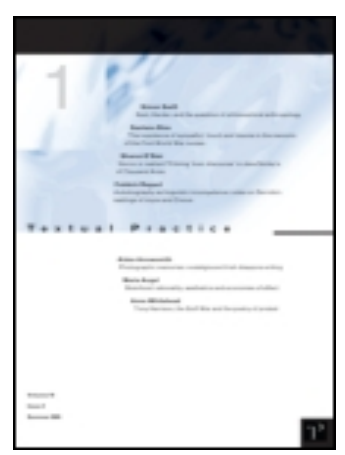

Textual Practice

ISSN: 0950-236X (Print) 1470-1308 (Online) Journal homepage: https://www.tandfonline.com/loi/rtpr20

\title{
Global civil war and post-9/11 discourse in The Wasted Vigil
}

\section{Oona Frawley}

To cite this article: Oona Frawley (2013) Global civil war and post-9/11 discourse in The Wasted Vigil , Textual Practice, 27:3, 439-457, DOI: 10.1080/0950236X.2013.784024

To link to this article: https://doi.org/10.1080/0950236X.2013.784024

曲 Published online: 30 May 2013.

Submit your article to this journal ๘

Џ Article views: 860

Q View related articles $\sqsubset$

4 Citing articles: 3 View citing articles 둔 


\section{Oona Frawley}

Global civil war and post-9/11 discourse in The Wasted Vigil

Nadeem Aslam's The Wasted Vigil offers the opportunity to consider the ways in which notions of civil war in the twenty-first century are complicated both by legacies of colonialisms and by contemporary discourse on extremism. Though the Afghanistan represented in the text is shown to be in a state of civil war stemming from tribal conflict, it is, simultaneously, an occupied space with an inheritance of multiple occupations. This palimpsestic arena serves as a meeting ground for key characters, each of which hails from and so represents a distinct part of Afghanistan's legacy. The novel also offers a meditation on the nature of extremism and its representations in the post-9/11 era. If, as Baudrillard suggests, terrorism like that enacted on 11 September 2001 succeeds because of its symbolic value, Aslam's novel pursues the notion of the symbolic through language as a way of moving beyond the standoff created by current-day (and largely American) rhetoric about extremism. The 'global civil war' enacted in the pages of The Wasted Vigil thus offers a critique not only of definitions of civil war, but also, and perhaps more significantly, a far more damning critique of the American-centric perspective on globality and media's normalization of the unimaginable image.

\section{Keywords}

Nadeem Aslam; global civil war; post-colonialism; terrorism; terrorist discourse; extremism; post-9/11 fiction 
Nadeem Aslam's novel, The Wasted Vigil offers the opportunity to consider the ways in which notions of civil war in the twenty-first century are complicated both by legacies of colonialisms and by contemporary discourse on political extremism. Though the Afghanistan represented in the novel is shown to be in a state of civil war stemming from tribal conflict, it is, simultaneously, an occupied space with an inheritance of multiple occupations. This palimpsestic arena serves as a meeting ground for key characters, each of which hails from and so represents a distinct part of Afghanistan's legacy. In drawing together under one roof four distinct characters - a British doctor who converted to Islam in order to marry his Afghani wife; the sister of a Russian soldier who disappeared in Afghanistan; a former CIA agent struggling with the implications of his past actions; and a young Pakistani extremist - Aslam conjures the impact of political and social strife on a particular space over several generations. The novel also offers a meditation on the nature of political extremism and its representations in the post-9/11 era. If, as Baudrillard suggests, terrorism like that enacted on 11 September 2001 succeeds because of its symbolic value, Aslam's novel pursues the notion of the symbolic through language as a way of moving beyond the standoff created by current-day (and largely American) rhetoric about extremism. As a homage to Ondaatje's The English Patient, itself a gathering of 'others' and an exploration of colonial legacies, The Wasted Vigil goes far in arguing for the impossibility of 'civil war' in a colonial/postcolonial space.

\section{Aslam in context: the global author}

Despite acclaim and book awards, Aslam remains little addressed in critical discourse. Given the continuance of conflict in Iraq and Afghanistan and the relevance of his work as a commentary on extremism and 'the war on terror', this is surprising on one level. However, western critical discourses generally struggle to situate authors born in arenas related to the post-9/11 conflict and who now live in the west. Aslam was born in Gurjanwala and moved to England as a teenager, in a migration pattern echoed in the personal trajectories of other authors of international bestsellers rooted in the same region: Mohsin Hamid, author of The Reluctant Fundamentalist (2007), was born in Lahore, spent the early part of his life between the USA and Pakistan, and now divides his time between the USA, Pakistan, England, and the Mediterranean; Khaled Hosseini, author of The Kite Runner (2003), was born in Kabul and lived in Iran and in Paris before settling in the USA. Websites providing biographies of Hosseini, as well as interviews with the author, stress his American citizenship, while Hamid is described as having acquired dual citizenship in 
England. ${ }^{1}$ These descriptors suggest that the national identification of an author plays a not insignificant role in determining his or her reception. What such authors have in common, then, is the continued assessment of their place in book reviews and interviews: a continuing curiosity about where they live, where they are rooted, how they identify themselves. In the post-9/11 world, though, the admission that an author has a fluid national identity is arguably more contentious, since such an admission challenges national loyalties that have been reasserted since the fall of the Twin Towers.

Aslam has shown himself to be a writer increasingly drawn to palimpsestic space, and to the problems and tensions that arise when multiple cultures inhabit the same arenas. While set exclusively in the Pakistan of the author's childhood, Season of the Rainbirds (1993) suggested a talent for coping with a wide cast of characters and deploying them to create a layered text, in this case one that explored the political corruptions of small-town life against the implied backdrop of the historical and wider political dimensions of the India-Pakistan conflict. Maps for Lost Lovers (2004), the masterly follow-up, saw the transfer of Aslam's focus to an unnamed location in England. In the anonymous town, we witness a year in the life of a Pakistani community as it struggles in the aftermath of the honour-killing of an unmarried couple whose disregard for social mores throws into relief the conflicts between generations; it also throws into relief conflicts between those who have changed their perspectives based on their English experience and those who find themselves unable or unwilling to bend. The rapturous reviews of Maps, which Aslam referred to as his 'immigrant novel', increasingly situated him amongst multicultural British writers. ${ }^{2}$ What sets Maps for Lost Lovers apart from some contemporary writing in England is the refusal of a template that considered the immigrant only within the context of 'English England'. ${ }^{3}$ In some ways, then, Aslam did not fit easily into the identity of a 'multicultural British author' who considered the immigrant within the context of the larger British social milieu.

If this refusal to conform to a template of the immigrant novel marked Aslam's second publication, there were other notable differences from his contemporaries as well. Whereas Zadie Smith's strength as a writer lies in a sharp wit and pace and a keen ear for the difference of speech in varied communities and generations, Aslam's style and voice owes more to contemplative, evocative notes like those found in the writing of Michael Ondaatje. Ondaatje, who was born and grew up in Sri Lanka and lived in England before moving to Canada, has set novels in national spaces beyond those of immediate connection to his own upbringing - in addition to making use of Sri Lanka, French- and English-speaking Canada, he has set parts of novels in the USA, Italy, France, and North Africa. Because of this, 


\section{Textual Practice}

Ondaatje is perhaps best considered a global writer, one whose personal national ties are not necessarily the prime determinant of the setting of his novels: it would be disingenuous to call him a Sri Lankan writer or a Canadian one, since this would ignore much of what his writing aims to achieve, which is a mapping of interconnections not limited to the national. Both Ondaatje's writing style and his liminal position as an author whose works resist national assignation can be seen as strong influences on Aslam. Born in Pakistan to Communist parents who had to flee Zia's regime, Aslam arrived in England as a teenager, and like Ondaatje seems to have divided affinities as an author: he has spoken in interviews about his research in Afghanistan for The Wasted Vigil, describing how in some places he needed to identify himself as Pakistani because of anti-British sentiment, and at other times as a British national because of anti-Pakistani feeling. ${ }^{4}$ The personal model of the immigrant with shifting identities aside, however, the strongest link between Ondaatje and Aslam exists in their exploration of those spaces in which people from a variety of backgrounds and nation-states gather: Aslam, like Ondaatje, is probably best categorized as a global novelist. This term 'global novelist' is used here to indicate an author whose work not only goes beyond the boundaries of their 'home' nation, but who is also concerned with global processes of war and migration, and with globalization generally; it also indicates the fact that such authors are writing for a global - and not a narrowly local - audience, and, because of international publishing, have access to a wide audience.

\section{Civil war or global war?}

Afghanistan, one of the most overwritten geographical spaces on earth, seems a particularly apt setting for a novel by a global author drawn to the palimpsestic, to the suggestion that identities and ideas are consistently overwritten by the broader historical and cultural events that surround us as individuals. The choice of Afghanistan as the setting is also, of course, a declaration that the novel is inherently political; in the post-9/11 world, it could not be seen otherwise. Aslam has made it clear in interviews that he deems all writing a political act:

I always say that I vote every time I write a sentence ... Coming from Pakistan, and belonging to the Islamic world, I can't not be aware of how politics affects our daily lives, how it is not just dry legislations and laws and statements. It's visceral. ${ }^{5}$

Interestingly, Aslam had planned to write The Wasted Vigil almost a decade before the events of 9/11: 
In 1992, when I finished my first novel I more or less tossed a coin to determine what book I would write next: my Afghanistan novel or my British-immigrant novel. Both subjects seemed equally urgent - a bloody civil war had begun in Afghanistan, and the Pakistani immigrant community in Britain seemed well advanced on the path that would lead to the suicide bombings on July 7, 2005. I began to write Maps for Lost Lovers, my immigrant novel, and as soon as I finished it in spring 2003, I started work on The Wasted Vigil.

When in the 1980s, the USA and Saudi Arabia began funding and arming the Afghan mujahidin, my family and friends in Pakistan were among the people who warned about the dangers of giving billions of dollars' worth of weapons to Islamic fundamentalists. The predicted horror was unleashed onto the people of Afghanistan soon enough, but it took decades for it to reach the wider world on September 11, 2001 the consequences became apparent to everyone.

I wanted to explore and record all of that in The Wasted Vigil. Afghanistan - a crossroads of history - seemed an appropriate place to discuss the meeting of Islamic and Western culture, the 'civilising missions' and the 'bringing of democracy'.

Aslam thus had what can justly be called a canny sense of the issues pressing down upon communities in Afghanistan; that 9/11 and its fallout occurred meant another layer was added to what became The Wasted Vigil.

The war in Afghanistan was funded by foreign sources that had stakes in the region by virtue of former colonial occupation and because of economic interests which ranged from the mining of gems to the production of opium and heroin poppies. There was also the fact of Afghanistan's geographical location amidst oil-rich states and at a perceived crossroads between east and west. Additionally, in the post-9/11 era, its increasing use as a base for radical groups with global aims comprised of mostly non-native Afghanis, notably, al-Qaeda. Civil war in Afghanistan was thus not a simple matter of one group pitted against the state, but a complex meshing of centuries' worth of global and local expectations and desires.

While The Wasted Vigil makes reference to ancient Afghani history most particularly to the fact of the presence and significance of Buddhism in the region - it deals primarily with the impact of twentieth-century imperialism. Through the character of the British-born Marcus, whose father was a doctor stationed and ultimately murdered in Afghanistan in the early part of the century, we receive references to the British colonial presence in the region in the late nineteenth century. Through 


\section{Textual Practice}

David, who spent some of his youth backpacking through the region before joining the CIA, we hear of the jostling for power that occurred between the Russians, the Pakistanis, and the Americans; through David we also receive information about the subversive American presence in Afghanistan through the decade of Soviet occupation. Lara's quest to find her lost brother, Benedikt, allows the novel to delve into that decade of Russian occupation, from 1979 to 1989. The novel's present day, though, is the 'civil war' period, which is generally annotated as being from 1989 to the present, and includes the takeover by the Taliban as well as the occupation by the Americans and British coalition following $9 / 11$.

The term 'civil war' pointedly does not often occur in the novel in relation to contemporary events; it functions instead as a muted verbal absence. The term first appears while David, the former CIA agent who now returns to Afghanistan with the aim of building schools, is in the town of Usha:

He stands at a crossroads and looks around, suddenly finding himself lost, surrounded by noise and talk. The men and women of Afghanistan share between them a store of tales so extensive, so rich and ancient, that it has been said it is unrivalled by any other land. Alexander passed through here in 329 BC with thirty thousand troops, and so now a man selling what look like centuries-old Greek coins approaches David. The years of war and civil war have emptied this country's museums. One 190-carat diamond in the sceptre of Russia's Catherine, bought by her from an Armenian gem merchant, was first the eye of a god in a temple in India, and so it is that no one can be certain where most of Afghanistan's looted treasures have ended up. ( WV, p. 60) $)^{7}$

Civil war, then, is introduced not on its own, but in relation to a more general, more broadly undefined 'war' that has 'emptied this country's museums': civil war, the implication is, has occurred and continues to occur in partial relation to this other type of war, and has been set in motion by the economic interests in the landscape that had such gems buried in its soil. Aslam's text attempts to outline this economic interest as ancient, through the image of the diamond taken at some point from Afghanistan, placed in the eye of a statue in India, and then looted to end up in first an Armenian's hands and then a Russian ruler's. This long-reaching economic interest by outsiders in Afghanistan is repeated in various contexts: Marcus muses on the fact that 'The lapis lazuli of their land was always desired by the world, brushed by Cleopatra onto her eyelids, employed by Michelangelo to paint the blues on the ceiling 
of the Sistine Chapel...' (WV, p. 16). David meets Zameen, Marcus's daughter, while in the CIA, but his cover is as

a dealer in gems. Someone who knew by heart the co-ordinates of where to locate various stones. Spinel: $34^{\circ} 26^{\prime} \mathrm{N}, 64^{\circ} 14^{\prime} \mathrm{E}$. Emerald: $35^{\circ} 24^{\prime} 59^{\prime \prime} \mathrm{N}, 69^{\circ} 45^{\prime} 39^{\prime \prime} \mathrm{E}$. Someone who knew that Kublai Khan had paid as much as 170,000 ting for Afghan rubies. And that the world's earliest known spinel was discovered in a Buddhist tomb near Kabul in 101 BC. (WV, p. 65)

Such references underline the fact that Afghanistan has been raided for commodities for millennia, and that the current-day occupation of the country mimics and echoes earlier invasions and raids. 'This country', the narrative tells us early on, 'was one of the greatest tragedies of the age. Torn to pieces by the many hands of war, by the various hatreds and failings of the world. Two million deaths over the past quartercentury' ( $W V$, p. 12).

There are, significantly, 'many hands of war' which contribute to the blurring of the notions of 'civil war' and 'war' throughout the novel, and to the impossibility of extricating these wars from economic concerns. During his heyday as a CIA agent batting between Pakistan, Afghanistan, and the USA in the early 1990s, David overhears a conversation at an embassy event in Islamabad between Fedalla, a corrupt character that shadows David's career and some of his companions. Fedalla comments on

How the influx since 1979 of the millions of filthy Afghan refugees had ruined the once beautiful city of Peshawar... led to what he termed the "Kalashnikovisation" of his homeland. "Look at the shapes of the two countries on a map and you'll see that Afghanistan rests like a huge burden on poor Pakistan's back. A bundle of misery".

They then move on to discuss the bombing of Kabul, 'the civil war having begun' ( $W V$, p. 166). The fact that the Afghani 'civil war' is not confined to its borders is clear, the artificiality of the line between Afghanistan and Pakistan is made amply apparent by the sense of regional chaos that Aslam evokes. ${ }^{8}$ 'Civil war', Aslam's novel observes, is a misleading term.

What we have been taught to think of when we hear the term 'civil war' is an internal conflict whose origins lie within national boundaries. Aslam's novel illustrates that instead of civil wars we are now in the realm of what Hardt and Negri have termed 'global civil wars' (p. 4)', and what Kaldor calls 'new wars'. The novel demonstrates, in fact, what 
scholars have increasingly argued: that the term 'civil war' glosses over many situations to which it cannot (and arguably should not) apply. 'Conventional explanations of civil war often fail to perceive the substantial influence of international influences in the creation and maintenance of war-prone states', Ann Hironaka's recent work concludes (p. 7). ${ }^{10}$ Hironaka finds that not only has the incidence of civil war increased 165 per cent in the post-World War II era, but that 'civil wars' have become far longer in this period (p. 40). This is due in no small part to external intervention: 'On average, civil wars with interstate intervention, broadly defined, are 300 per cent longer than wars without intervention' (p. 51). Hironaka encourages a new consideration of the ways in which the world order functions in relation to so-called civil wars, since

Our analytical blindness to the prevalence of intervention is the result of the collusion of the international community, which insists that all states are sovereign actors. Thus intervention is ignored despite its pervasiveness, because acknowledgement of the multiple direct and indirect forms of intervention that support weak states might undermine assumptions about their sovereign status. (p. 25)

What Hironaka terms 'intervention' is, of course, in many cases, straightforward invasion or occupation; in others, it involves behind-the-scenes manoeuvring like that undertaken by the CIA in Afghanistan during and after the Russian occupation. 'Intervention' of either type, though, means that the old notion of an internal civil conflict is no longer appropriate. Those now outdated, simplistic viewings of 'civil war' allow for the 'intervention' by other states to be effectively glossed over and also for the overlooking of another major factor: if we accept the notion of 'tribal' or 'internal' conflict as being central to civil war, we go down the road of accepting that it is, by and large, an identity crisis that creates the conflict, or a grievance tied with identity formation without nation-states. While such grievances are almost always perceived as being the determining factor in starting a civil war, research has found that such grievances are, on the contrary, only minor mitigating factors in such conflicts. Economics and the fight over what the territory contains, owns and can export are the prime predictors of a state's chances of engaging in civil war. ${ }^{11}$ The process whereby 'civil wars' like those examined by Hironaka have lengthened and seem, as her title puts it, 'neverending' (p. 1), indicates just how powerful the economic drive behind such wars are. Hardt and Negri convincingly argue that war is now 'becoming a general phenomenon, global and interminable' (p. 3). Even amongst academics still inclined to believe in the old parameters of 'civil war', there is 
an admittance of these issues. In one of the few assessments of civil wars in postcolonial states the authors concede that

Although we believe that the root of insurgency is found in the postcolonial states themselves, nevertheless, one is reminded that the fragility of these states is in large measure one of the lingering byproducts of their former colonial domination. Moreover, as was so often the case, the superpowers and their major and minor power allies, who were motivated by imperial reminiscences and/or Cold War exigencies, often threw gasoline on the smoldering conflicts in post-colonial states. One result was that as the major powers enjoyed a 'Long Peace', the post-colonial states were plagued by a 'Long Trauma'.

When we consider the current Afghani 'civil war' in this light what becomes immediately apparent is the absurdity of deeming it to be an internal conflict deriving from an identity crisis of local or even regional proportions. Following the defeat and departure of the Russians in 1989, the country that had been torn asunder for more than a century by political, military, and financial interests reverted to the rudderless course dictated by occupation and abrupt departure. Mahmood Mamdami writes that

Perhaps no other society paid a higher price for the defeat of the Soviet Union than did Afghanistan. Out of a population of roughly 20 million, a million died, another million and a half were maimed, and another five million became refugees. UN agencies estimate that nearly a million and a half have gone clinically insane as a consequence of decades of continuous war. Those who survived lived in the most mined country in the world. Afghanistan was a brutalized society even before the present war began. ${ }^{13}$

The violent course of present-day Afghanistan has been read, in popular media accounts and in western assessments of Afghanistan's predicament, as the consequence not of multiple occupations and continued interference by western governments but of the country's inability to govern itself. Aslam's novel serves up challenges to such stereotyping through its insistence on representing civil war alongside colonial invasion and occupation.

\section{The Afghani past, the global past}

In the grounds of Marcus's house lies buried a Buddhist statue symbolic of Afghanistan's history as a centre for Buddhist thought and for a more diverse and tolerant approach to religion, a history largely buried and 
neglected in contemporary media coverage. The province, Marcus knew, 'was one of the most important pilgrimage sites in the Buddhist world from the second to the seventh centuries $\mathrm{AD}$ - over a thousand Buddhist stupas in the area echoing the incantations of monks back then...' ( $W V$, p. 19). The buried Buddha, resting peacefully amid the chaos of generations, is airlifted to the museum in Kabul at the novel's close, exposed and now vulnerable; despite the efforts of the Taliban to shoot at it with their guns, it has survived mostly unscathed underground. Marcus's Buddha stands in marked contrast, of course, and mutely alludes to the Bamiyan Buddhas destroyed by the Taliban in 2001. There is a sense in which Marcus's Buddha is one of Afghanistan's few remaining cultural artefacts.

The peacefulness of the buried Buddha is offset, of course, against the strife that surrounds and threatens it. David, whose CIA past haunts him, recognizes that 'The entire world it seemed had fought in this country, had made mistakes in this country, but mistakes had consequences and he didn't know who to blame for those consequences. Afghanistan itself, Russia, the United States, Britain, Arabia, Pakistan?' (WV, p. 34). The 'entire world' is wrapped up in what is shown to be a space not marked simply by civil war but by the chaos of empires fighting over territory and its valuables. Even when the novel considers ongoing and intergenerational conflict between tribal warlords, we are made aware of the fact that this conflict is continually subject to external interference.

The novel emphasizes not merely the empire building that continues to take place in Afghanistan but also provides a sense of the ways in which all empires have functioned: by taking over space, by invading, by asserting control through brutality. Through David, who has an interest in Native American history, we see the USA as a colonizing enterprise from its earliest days; Native Americans were slaughtered and then integrated into a sanitizing national narrative evident in the names of American weaponry sometimes cited in the novel (the Tomahawk missile, for instance). David also ruminates on the American war in Vietnam, where his beloved brother Jonathan disappeared, presumed dead. The loss of Jonathan was enough to provoke a prolonged grief that involved David following a circuitous route into the military himself, so that one brother's sacrifice of his life fearfully fighting against the spectre of Communism leads to another brother's spying against Communism in a different region. Jonathan's watch, which David cherishes, had an Afghani spinel in it, and 'That was one of the reasons I came to this country all those years ago. Always wanted to visit Afghanistan because of that small jewel', David tells Lara (WV, p. 94). When the Soviet Union - the same Communist threat that had led to the Vietnam War - invaded Afghanistan, David's interest was further aroused. 'The Soviet Union 
had supported Vietnamese guerrillas and had thus played a role in the disappearance and probably death of his brother' (WV, p. 128). David's hatred of Communism reveals the ways in which ideology can become deeply personal, providing him with the impetus to go to work for the CIA.

If David encapsulates a history of American military intervention and empire building during the Cold War, Lara represents the Soviet side of the equation. Daughter of a cosmonaut, and wife of a highranking military man, Lara is reluctantly enmeshed in the Soviet empire's bid for power. Like David, though, she has lost everything to the empire's aims, and through her we witness its messy, unrelenting and far-reaching effects: not only has she lost her father, brother, and mother, but, in a plot strand that engages with the rise of Islamic radicalism in Soviet satellites, her husband is tortured and murdered, within her hearing, after he testifies in support of comrades accused of torturing Chechen rebels. The individuals of the novel are thus shown to be representatives of global conflicts. A description of David observing Zameen bathing captures the inherent interconnectedness of such conflicts: 'He watched her pour water onto her shoulder when she bathed, the water spreading in a thin layer on her skin and then breaking up into shapes that resembled countries and islands, resembled continents' ( $W V$, p. 146). The individual is subject to the world and to global conflicts, the fragile body subject to the shifting of borders and the provocations of nations.

The interconnectedness of the wars that have so deeply affected Aslam's characters is apparent when Lara, having heard David speak of his brother, thinks about Vietnam.

A different war - but maybe at some level it was the same war. Just as tomorrow's wars might be begotten by today's wars, a continuation of them. Rivers of lava emerging onto the surface after flowing many out-of-sight miles underground. ( $W V$, p. 312)

Lara's musing suggests that we are too hasty in considering wars in different regions and at different times in isolation; subtly highlighting the reality of a global civil war in the twenty-first century.

\section{Homage and trauma}

In our consideration of the war in Afghanistan as part of a global phenomena and a global system the fear is one of historical decontextualization. This process is, however, encouraged by widespread media coverage of 
the war in Afghanistan normalizing its long duration by projecting it as part of a wider 'war on terror'. Aslam's novel combats these tendencies in several key ways. As a novel demanding far more attention than is required by a news broadcast or a newspaper article, The Wasted Vigil forces its readers to spend time in Afghanistan, and to consider not the distant, implied trauma of the numbers of dead that govern media reports, but individualized narratives of trauma. In this sense, the novel crucially allies itself with the stance taken by critics like Judith Butler, in Frames of War, who suggests that certain lives are not deemed 'grievable' in media coverage, not worth consideration in life or death. ${ }^{14}$

The Wasted Vigil opens with a homage to Ondaatje's The English Patient that creates a sense of the trauma experienced by the characters we meet. On the first page we find Lara, recently returned to Afghanistan in search of news of her brother, peering at books in the home of her host, Marcus. It is clear from the novel's opening line that her experience of trauma is near clinical: 'Her mind', we read, 'is a haunted house' ( $W V$, p. 1). Cathy Caruth's description of post-traumatic stress provides insight into Lara's state:

$[\mathrm{M}]$ ost descriptions [of post-traumatic stress] generally agree that there is a response, sometimes delayed, to an overwhelming event or events, which takes the form of repeated, intrusive hallucinations, dreams, thoughts or behaviours stemming from the event, along with numbing that may have begun during or after the experience, and possibly also increased arousal (and avoidance of) stimuli recalling the event... This simple definition belies a very peculiar fact: the pathology cannot be defined either by the event itself - which may or may not be catastrophic and which will not traumatize everyone equally - nor can it be defined in terms of a distortion of the event, achieving its haunting power as a result of distorting personal significances attached to it. The pathology consists, rather, solely in the structure of its experience or reception: the event is not assimilated or experienced fully at the time, but only belatedly, in its repeated possession of the one who experiences it. To be traumatized is precisely to be possessed by an image of the event. ${ }^{15}$

Lara's life story, if compressed into the space of a few sentences, would seem melodramatic and perhaps even unbelievable, but Aslam, far from compressing material, feeds it to his reader slowly; the narrative, in fact, mimics the functioning of traumatic memory, with events of the past appearing in fragments, in intrusive flashbacks, from different perspectives, never wholly experienced. Like Ondaatje's Hana in The English Patient, Lara has lost everyone she loves; like Hana, she finds 
herself in a house that has been subjected to sieges, and in which books become literally part of the building. In an attempt to repair the Italian villa whose walls, scarred by bombs, now gape like windows at the views of the countryside, Hana stacks and nails books together to solve the problem of missing stairs. Marcus's dead wife, Qatrina, nailed them instead to the ceiling, trying to hide their subversive presence from the Taliban; books here become the roof over the characters' heads, a structural part of the home. Aslam's Lara echoes Hana in those opening pages as she considers the books and plucks one down; even the mirror that she slides across the floor to aid her selection recalls the fragments of mirror that Hana has tied on stakes in her vegetable patch to frighten birds away. We have here what seems a deliberate set of textual references to Ondaatje's Booker Prize-winning novel.

The intertextuality functions to remind us of a major theme of Ondaatje's novel. Madox in The English Patient remarks that in the desert, nations did not matter: their exploration and mapping expeditions, Madox suggests, are somehow above the ideologies that govern the nations at war all around them. This idealistic view is not one that Ondaatje's text seems to share, on balance; the romance of exploration perceived by the explorers blinds them to their own involvement in a variety of colonial and empire-building enterprises that the war encompasses and represents. Higher intentions or devotion to some perceived global good - the mapping of some of the least known places on earth, and the discovery of caves decorated with paintings thousands upon thousands of years old - do not translate, in the novel, into a 'way out' or a bypassing of moral responsibility - just as, in The Wasted Vigil, David's funding of schools does not compensate for his past actions and interventions on behalf of the CIA. Nations and nationalities do matter, and character after character enacts a fate that relies in no small part on narratives based on their national attachments and the traumas to which they have been subjected.

\section{Possession by the image}

'To be traumatized is precisely to be possessed by an image of the event', Caruth argues. In the post-9/11 era a particular set of images have been repeatedly fed to us through popular; if this force-feeding began with the collapse of the Twin Towers, it has continued unabated with images of war in Iraq and Afghanistan - and the two are often undifferentiated, precisely underlining the global nature of this war. Aslam's novel presents a series of challenges to images that have come to dominate post-9/11 discourse and its rhetoric that emphasises 'the war on terror', achieving this not only by 


\section{Textual Practice}

demonstrating how thoroughly traumatized his characters are, but through characters opposing thoughts on extremism and a critique of media. Post9/11 rhetoric is challenged most forcefully by Casa, the young jihadi who, it seems likely, is Zameen's lost son:

These days they keep saying, Why do Muslims become suicide bombers? They must be animals, there are no human explanations for their actions. But does no one remember what happened on board flight United 93? A group of Americans - 'civilised' people, not 'barbarians' - discovered that their lives, their country, their land, their cities, their traditions, their customs, their religion, their families, their friends, their fellow countrymen, their past, their present, their future, were under attack, and they decided to risk their lives - and eventually gave up their lives - to prevent the other side from succeeding. He is not wrong when he thinks that that is a lot like what the Muslim martyrdom bombers are doing. (WV, p. 212)

Aslam forces a recognition in a western readership that people on opposite sides of the 'war on terror' share much more in common than media representation and post-9/11 rhetoric would have us believe. In this way Aslam's novel contains a fascinating thread that deconstructs and critiques such rhetoric through an examination of its representation in media, and the ways in which, in Baudrillard's terms in 'The Spirit of Terrorism', we are subject to the spectacle and remain in thrall to the image:

...what stays with us, above all else, is the sight of the images. This impact of the images, and their fascination, are necessarily what we retain, since images are, whether we like it or not, our primal scene. And, at the same time that they have radicalized the world situation, the events in New York can also be said to have radicalized the relation of the image to reality. (pp. 26-27) ${ }^{16}$

Lara's consideration of the Cold War and the ways in which it played upon fear through a succession of images illustrates Aslam's tactic by linking the fear inspired by the Cold War to the events of 9/11. She remembers that both the Soviets and the Americans planned to nuclear bomb the moon:

Yes, after such a demonstration who wouldn't cower beneath a nuclear-armed Soviet moon, a nuclear-armed American moon? It never happened but she wonders if the terrorists didn't come close to something like it in 2001, an enormous spectacle seen by the entire world, planting awe and shock in every heart. ( $W V$, p. 32) 
Lara's thought, of course, represents not only the 'awe and shock' experienced by those reacting to $9 / 11$, but also slyly points to the 'shock and awe' tactics subsequently employed by the US military in its own campaign.) The 'spectacle' of 9/11 consumed around the world initially seemed compelling because, according to Baudrillard, it was the spectacle of global capitalism, even globalization itself, 'committing suicide' (p. 4). The fact that this happened 'live', that it was witnessed by so many and that it resembled filmic apocalypses meant that it fit into cognitive expectations. The spectacle relied, in other words, on our past experience of the image, and even our expectation of it, according to Baudrillard:

[W] have dreamt of this event, that everyone without exception has dreamt of it - because no one can avoid dreaming of the destruction of any power that has become hegemonic to this degree... At a pinch, we can say that they did it, but we wished for it. (p. 5)

The fact is, Baudrillard argues, that 'The countless disaster movies bear witness to this fantasy...' (p. 7), the acting out of which amounts to 'triumphant globalization battling against itself (p. 11).

The confusion and overlap between reality and the simulacrum image is subtly mapped by Aslam. Casa recalls being with Bihzad prior to Bihzad's suicide mission, sitting in a room, 'in that interior filled with crates of rocket-propelled grenades, packets of explosives that smelled like almonds, and boxes full of DVDs and CDs depicting jihad as Allah the Almighty saw it and not as the world's media distorted it' (WV, p. 56). Casa has been trained to read media as he was taught to read generally:

Having studied manuals for weapons and computers, for microprocessors and motherboards, having taken lessons in passport and credit-card forging, and having carefully examined news footage of almost every attack ever mounted on Western targets, he knows the English language. He had helped put together films at the jihadi camps in that language, to be sold in the mosques of European cities after Friday prayer - propaganda and preaching, the Jihad of the Tongue. (WV, p. 181)

The group with which Casa allies himself sees media as another tool in its arsenal unconsciously reflecting Baudrillard's argument regarding the endurance of the image. It is not just his own propaganda that he consumes, however, and it is not merely to critique the representation of Islam that media is scrutinized: 'Casa and the others sometimes watch Hollywood action movies at the training camps, 


\section{Textual Practice}

searching for ideas and inspiration. The burning exploding American cities were their dreams made real on the screen...' (WV, p. 239).

The young American extremist, James, is also a consumer of the mediated image and, like Casa, unaware of his own bias. He muses on the ways in which local people ask for his help to get to the USA:

There is every possibility that disappointment and rage await them at the end of the journey to the West. Earlier, he had seen them riveted by the DVD of a Hollywood thriller - every scene was full of sleek cars or shiny women or blasting guns - making him understand why the rest of the world thought Americans were crazy. Only minutes later, however, he wasn't too sure. When you learn that the rest of the world thinks this is what life in America is like, that this isn't just throwaway entertainment, isn't understood by sane Americans as fantasy or momentary diversion, you realise how crazy the rest of the world is. ( $W V$, p. 277)

James's confusion - 'he wasn't too sure' - amounts to an admission that he too is thrown by the image of America he consumes on film, uncertain of what is real and what is not. Islam's rejection of the image generally is seen as canny in this regard, an avoidance of the bewilderment that comes with viewing and participating in a simulacrum. ${ }^{17}$ Baudrillard asks, at the end of 'The Spirit of Terrorism', whether the 'reality' of 9/ 11 and its aftermath 'outstrips fiction':

If it seems to do so, this is because it has absorbed fiction's energy, and has itself become fiction. We might almost say that reality is jealous of fiction, that the real is jealous of the image.... It is a kind of duel between them, a contest to see which can be the most unimaginable. (p. 28)

As a novel, The Wasted Vigil succeeds, rather ironically, in becoming a more 'real' rendering of events in Afghanistan than the rendering that we receive in media: fiction, in this case, is more real than the 'live' coverage to which we are subjected, since it ventures beyond the statistics delivered to us about Afghanistan and manages to evoke the trauma that people experience, even in a 'clean' war that media would have us believe leaves no casualties.

David, having witnessed Casa's torture by James at the novel's end, thinks, 'They don't need to watch jihadi DVDs to become radicalised: they'll just watch the evening news on the TV - with things like these 
being reported' ( $W V$, p. 350). The novel's closing pages thus point to the role media representation plays in the provocation of global civil war, a non-state actor intervening as much as state actors are shown throughout the novel. In this sense, The Wasted Vigil lays down a challenge not only to outdated definitions of civil war, but also to the newer notion of the global civil war as well. Heike Harting notes that

if global war is primarily a byproduct of and intrinsic to Empire and its consolidation, it appears to be inevitable and takes place outside discourses of political legitimization and accountability. From a different perspective, conceptualizing global civil war as being engineered by the Global North... reveals the ways in which global war deeply invests in and ensures the continuous accumulation of global capital and centralized practices of uneven capital distribution. Furthermore, if 'the global' designates... a cultural and social space inhabited by those who are impoverished, dispossessed, and violated by the economic and geopolitical restructuring of the world, then the 'global' also delineates a process of subject constitution governed by the construction of absolute difference, abjection, and dehumanization... I suggest that the term 'global civil war,' specifically when understood as a version of the US-led 'war against terror,' serves to normalize and legitimize the transformation of constitutional democracy into a permanent but unacknowledged state of exception. ${ }^{18}$

Drawing on Agamben's theories of both biopolitics and 'states of exception' as well as his reactions to American policy in the post-9/ 11 age, Harting here asks us to rethink the idea of the global. ${ }^{19}$ The civil war in Afghanistan is 'global' in the sense that it is the product of many forces beyond Afghanistan itself; it is also, however, shown to be 'global' in Heike's terms. The 'global civil war' enacted in the pages of The Wasted Vigil thus offers a critique not only of definitions of civil war, but also, and perhaps more significantly, a far more damning critique of the American-centric perspective on globality and media's normalization of the unimaginable image.

National University of Ireland Maynooth

\section{Notes}

1 See, for instance, Khaled Hosseini's official website: http://www. khaledhosseini.com/hosseini-bio.html, or the Wikipedia entry on Hosseini: http://en.wikipedia.org/wiki/Khaled_Hosseini. Hamid's official website, 


\section{Textual Practice}

http://www.mohsinhamid.com/shortbio.html, provides a biography, as does Wikipedia: http://en.wikipedia.org/wiki/Mohsin_Hamid.

2 http://www.bookbrowse.com/author_interviews/full/index.cfm?author_ number=1149 (accessed 1 February 2011).

3 See Aslam's comments on 'White England' in 'Writing Against Terror: Nadeem Aslam'. Michael O'Connor, July 2005. Three Monkeys Online. http://www.threemonkeysonline.com/als/_nadeem_aslam_interview.html (accessed 6 February 2011).

4 'An Interview with Nadeem Aslam about The Wasted Vigil. Book Browse. http://www.bookbrowse.com/author_interviews/full/index.cfm?author_ number $=1149$ (accessed 8 February 2011).

5 Ibid.

6 Ibid.

7 All references to The Wasted Vigil (London: Faber and Faber, 2008) are abbreviated from here on as $W V$.

8 This might also be seen as a mirror of current-day American rhetoric about 'AfPak' and what are perceived as increasing links between the two countries based on extremist groups; the rhetoric persists despite a general rejection of the term in Pakistan, which, given the lessons of history, might well shy away from another pairing with a neighbouring nation.

9 See Michael Hardt and Antonio Negri, Multitude: War and Democracy in the Age of Empire (London: Penguin, 2005). Page references to this work will be given in text.

10 Ann Hironaka, Neverending Wars: The International Community, Weak States, and the Perpetuation of Civil War (Boston, MA: Harvard University Press, 2008). Page references to this work will be given in text.

11 Paul Collier and Nicholas Sambanis (eds), Understanding Civil War: Evidence and Analysis. Volume I: Africa (Washington, DC: The World Bank, 2005), p. 16.

12 Errol A. Henderson and J. David Singer, 'Civil War in the Post-Colonial World, 1946-92', Journal of Peace Research, 37.3 (2000), pp. 275-299(295).

13 Mahmood Mamdani, 'Good Muslim, Bad Muslim: A Political Perspective on Culture and Terrorism', American Anthropologist, New Series, 104.3 (2002), pp. 766-775(773).

14 Judith Butler, Frames of War: When Is Life Grievable (Brooklyn: Verso Press, 2009).

15 Cathy Caruth, extract from 'Trauma and Experience' in Michael Rossington and Anne Whitehead (eds), Theories of Memory: A Reader (Edinburgh: Edinburgh University Press, 2007), p. 200.

16 Jean Baudrillard, The Spirit of Terrorism (London: Verso, 2002). Page references to this work will be given in text.

17 Casa notes that 'Allah forbids photography. The only exception to this a Muslim must reluctantly make in today's world is the photo needed for a passport: to go on the pilgrimage in Mecca, or to cross borders for the purposes of jihad' ( $W V$, p. 240). 
18 Heike Harting, 'Global Civil War and Post-Colonial Studies', Globalization Working Paper Series, Issue 06/3 (May 2006), p. 7.

19 See Giorgio Agamben, State of Exception (Chicago, IL: University of Chicago Press, 2005) and Homo Sacer: Sovereign Power and Bare Life (Stanford, CA: Stanford University Press, 1998). 